\title{
PENGARUH WAKTU PEMBEBANAN UJI KONSOLIDASI 1 DIMENSI TERHADAP NILAI OEDOMETRIC MODULUS TANAH SILTY CLAY
}

\author{
Andrias Suhendra Nugraha ${ }^{1}$, Sutan A. H. M. Manurung ${ }^{2}$ \\ ${ }^{1}$ Mahasiswa Program Doktor Ilmu Teknik Sipil, Universitas Katolik Parahyangan \\ dan Dosen Program Studi Teknik Sipil, Universitas Kristen Maranatha \\ Email: andrias.snugraha@gmail.com \\ ${ }^{2}$ Mahasiswa Program Studi S1 Teknik Sipil, Universitas Kristen Maranatha \\ Email: sutanmisar@gmail.com
}

\begin{abstract}
ABSTRAK
Investigasi geoteknik baik di laboratorium maupun di lapangan sangat penting dilakukan pada suatu pembangunan infrastruktur. Parameter yang diperoleh dari hasil investigasi geoteknik menentukan pula kualitas analisis dan desain pada suatu konstruksi. Pekerjaan bidang geoteknik yang umum dilakukan antara lain adalah analisis penurunan tanah. Parameter penurunan tanah dapat diperoleh dari hasil investigasi geoteknik dengan melakukan uji konsolidasi 1 (satu) dimensi di laboratorium. Salah satu parameter yang dihasilkan oleh uji konsolidasi tersebut adalah oedometric modulus, $\mathrm{E}_{\text {oed }}$.

Tujuan dari penelitian ini adalah untuk mengevaluasi pengaruh waktu pembebanan untuk setiap kenaikan beban (load increament) pada uji konsolidasi 1 dimensi di laboratorium terhadap nilai eodometric modulus. Metode yang digunakan adalah, membandingkan nilai $\mathrm{E}_{\text {oed }}$ hasil uji konsolidasi dengan waktu pembebanan 24 jam dan waktu pembebanan 48 jam untuk setiap kenaikan beban. Penelitian ini menggunakan 2 sampel uji (sample A dan sampel B) tanah silty clay yang diperoleh dari 2 lubang bor yang berbeda, dimana untuk setiap sampel uji dibagi menjadi dua, yaitu; 1 sampel untuk kondisi waktu pembebanan 24 jam dan 1 sampel lainnya untuk kondisi waktu pembebanan 48 jam untuk setiap kenaikan bebannya.

Hasil penelitian menunjukkan bahwa nilai $\mathrm{E}_{\text {oed }}$ dipengaruhi oleh waktu pembebanan pada saat tegangan konsolidasi efektif, $\sigma^{\prime}{ }_{\text {vc }}$ bekerja pada rentang; $200-400 \mathrm{kPa}$. Pada sampel A, nilai $\mathrm{E}_{\text {oed }}$ untuk waktu pembebanan 48 jam lebih besar $49,4 \%$ dari $\mathrm{E}_{\text {oed }}$ dengan waktu pembebanan 24 jam. Sementara pada sampel $\mathrm{B}$, nilai $\mathrm{E}_{\text {oed }}$ untuk waktu pembebanan 48 jam lebih besar $21,6 \%$ dari $\mathrm{E}_{\text {oed }}$ dengan waktu pembebanan 24 jam
\end{abstract}

Kata Kunci: konsolidasi, oedometric modulus, waktu pembebanan, load increament

\begin{abstract}
Geotechnical investigations both in the laboratory and in the field are very important to do in an infrastructure development. Parameters obtained from the results of geotechnical investigations also determine the quality of the analysis and design of a construction. The general work of the geotechnical field includes analysis of soil settlement. Parameter of soils settlement can be obtained from the results of geotechnical investigations by conducting of the 1 (one) dimension consolidation test in the laboratory. One of the parameters produced by the consolidation test is oedometric modulus, $E_{\text {oed }}$.

The purpose of this study was to evaluate the effect of loading time for each load increament on the 1 dimensional consolidation test in the laboratory to the eodometric modulus value. The method used is, comparing the $E_{\text {oed }}$ value of the consolidation test results with 24-hour loading time and 48-hours loading time for each load increment. This study uses 2 test sample of silty clay soil (sample A and sample B) obtained from 2 different drill holes, where for each test sample is divided into two condition as follows; 1 sample for a 24 hour loading time condition and 1 other sample for 48-hour loading time for each load increament.

The results showed that the value of $E_{\text {oed }}$ was influenced by the loading time when the effective consolidation stress, $\sigma_{v c}$ worked in the range; 200-400kPa. In sample A, the $E_{\text {oed }}$ for the 48-hour
\end{abstract}


loading time was $49,4 \%$ greater than $E_{\text {oed }}$ with 24 -hour loading time. While in sample $B$, the $E_{\text {oed }}$ for the 48-hour loading time was 21,6\% greater than $E_{\text {oed }}$ with 24-hour loading time.

Keywords: traffic engineering, traffic management, one-way system, Dukuh Atas, Vissim.

\section{PENDAHULUAN}

Investigasi geoteknik baik di laboratorium maupun di lapangan sangat penting dilakukan pada suatu pembangunan infrastruktur. Parameter yang diperoleh dari hasil investigasi geoteknik menentukan pula kualitas analisis dan desain pada suatu konstruksi. Pekerjaan bidang geoteknik yang umum dilakukan antara lain adalah analisis penurunan (settlement) tanah. Parameter penurunan tanah dapat diperoleh dari hasil investigasi geoteknik dengan melakukan uji konsolidasi 1 (satu) dimensi di laboratorium dengan alat uji oedometer. Salah satu parameter yang dihasilkan oleh uji konsolidasi tersebut adalah modulus terkekang (oedometric modulus), $\mathrm{E}_{\text {oed }}$.

Penelitian ini menggunakan 2 sampel uji tanah silty clay (sample A dan sampel B) yang diperoleh dari 2 (dua) lubang bor yang berbeda, dimana untuk setiap sampel uji dibagi menjadi dua, yaitu; 1 sampel untuk kondisi waktu pembebanan 24 jam dan 1 sampel lainnya untuk kondisi waktu pembebanan 48 jam untuk setiap kenaikan bebannya.

\section{TUJUAN DAN RUANG LINGKUP PENELITIAN}

Tujuan penelitian ini adalah mengevaluasi pengaruh waktu pembebanan terhadap nilai oedometric modulus, $\mathrm{E}_{\text {oed }}$ tanah silty clay berdasarkan kurva hubungan antara tegangan konsolidasi efektif, $\sigma_{\mathrm{vc}}$ dan regangan verikal, $\varepsilon_{\mathrm{v}}$ yang diperoleh dari uji konsolidasi satu dimensi di laboratorium. Ruang lingkup penelitian antara lain adalah:

1. Pengujian konsolidasi di laboratorium menggunakan metode One-Dimensional Consolidation of Soils Using Incremental Loading dengan mengacu standar ASTM D2435;

2. Sample tanah uji yang digunakan pada penelitian ini terdiri atas 2 sampel tanah tidak terganggu (undisturbed sampel) dari 2 lubang bor (BH01-UDS1 dengan kedalaman 0,49-0,71 m dan BH02-UDS02 dengan kedalaman 1,75 - 1.83m);

3. Tanah uji berasal dari Penajam, Kalimantan Timur;

4. Konsistensi tanah silty clay yang digunakan sebagai sampel uji adalah very soft;

5. Waktu pembebanan (load duration) untuk setiap siklus beban pada uji konsolidasi di laboratorium adalah 24 jam dan 48 jam;

6. Pengujian dilakukan di Laboratorium Mekanika Tanah, Program Studi S-1 Teknik Sipil, Universitas Kristen Maranatha, Bandung. 


\section{UJI KONSOLIDASI 1 DIMENSI DI LABORATORIUM}

Prosedur untuk melakukan uji konsolidasi satu-dimensi pertama-tama diperkenalkan oleh Terzaghi. Uji tersebut dilakukan di dalam sebuah alat oedometer. Skema sampel uji pada alat oedometer dan alat uji oedometer ditunjukkan dalam Gambar 1 dan Gambar 2.

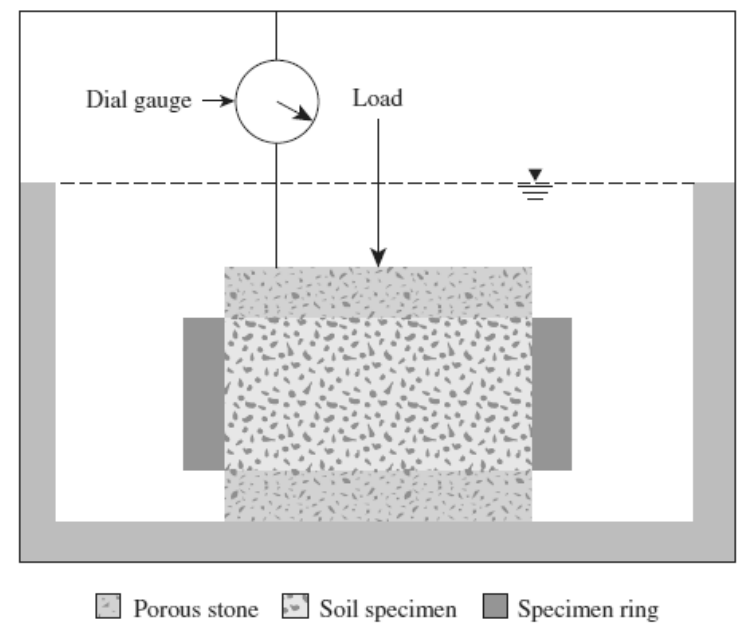

Gambar 1. Skema Sampel Uji pada Alat Oedometer (Das and Sobhan 2014)

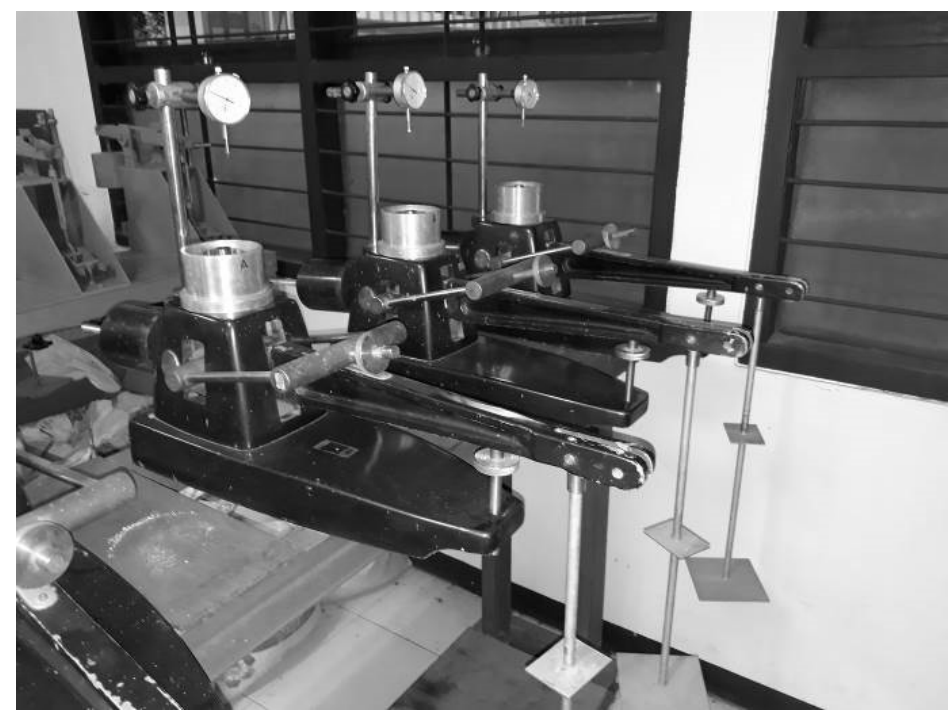

Gambar 2. Alat Uji Oedometer di Laboratorium

Hubungan antara waktu dan deformasi untuk suatu siklus beban yang dihasilkan uji konsolidasi 1 dimensi di laboratorium dinyatakan oleh kurva time - deformation seperti tampak pada Gambar 3. 


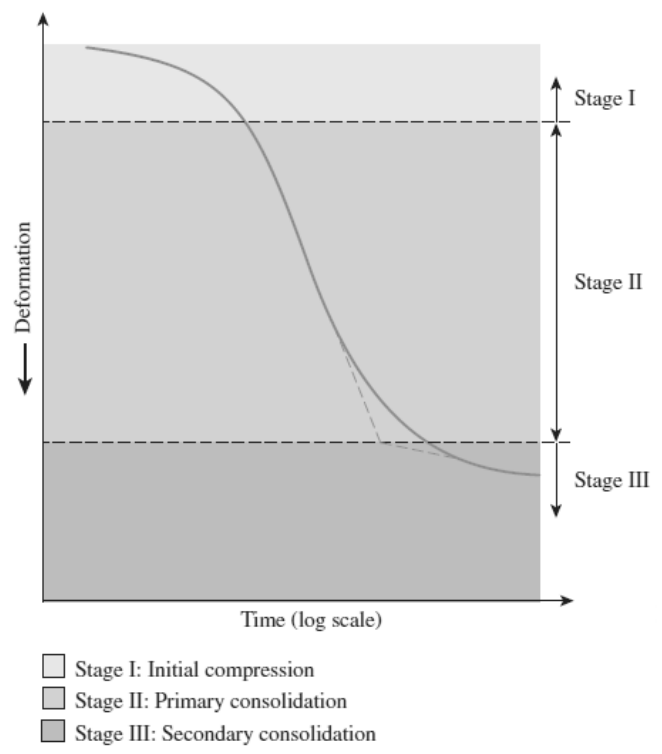

\section{Gambar 3. Kurva time - deformation untuk Suatu Siklus Beban}

\section{(Das and Sobhan 2014)}

Berdasarkan Gambar 3, terdapat tiga tahapan proses konsolidasi yaitu:

- Stage I: Pemampatan awal (initial compression), yang pada umumnya disebabkan oleh pembebanan awal (preloading).

- Stage II: Konsolidasi primer (primary consolidation), yaitu periode selama tegangan air pori berlebih (excess) secara gradual ditransfer menjadi tegangan efektif, sebagai akibat dari keluarnya air dari pori-pori tanah.

- Stage III: Konsolidasi sekunder (secondary consolidation), yang terjadi setelah tekanan air pori excess mengalami disipasi (dissipation) dan kondisi dimana deformasi tanah yang diakibatkan oleh plastic readjustment dari struktur (frabric) tanah.

Terdapat dua cara untuk penyajian data hasil uji konsolidasi yaitu:

1. Kurva hubungan antara regangan vertikal (vertical strain), $\varepsilon_{\mathrm{v}}$ dan tegangan konsolidasi efektif (effective consolidation stress), $\sigma{ }_{\mathrm{vc}}$.

2. Kurva hubungan antara angka pori (void ratio), e dan tegangan konsolidasi efektif (effective consolidation stress), $\sigma^{\prime}$ vc. 


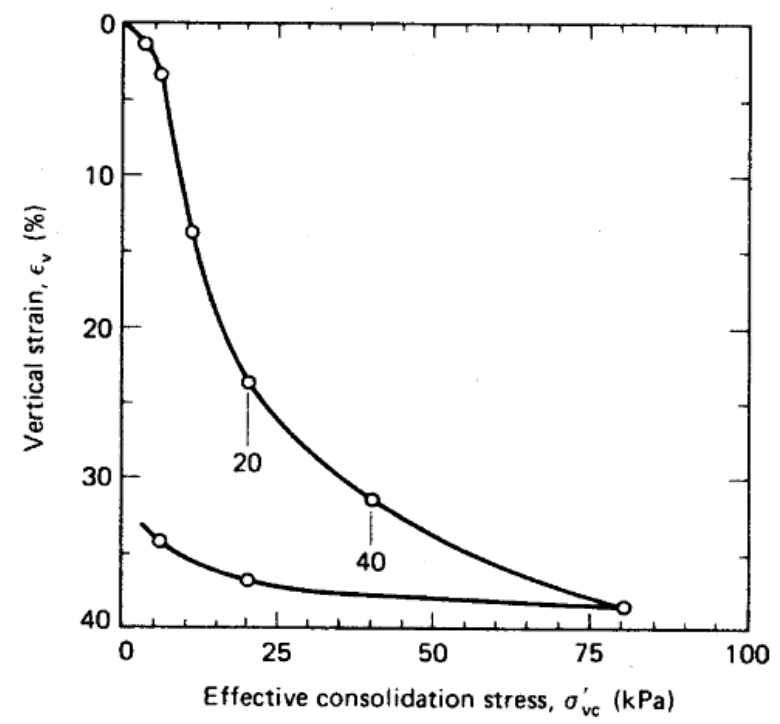

(a)

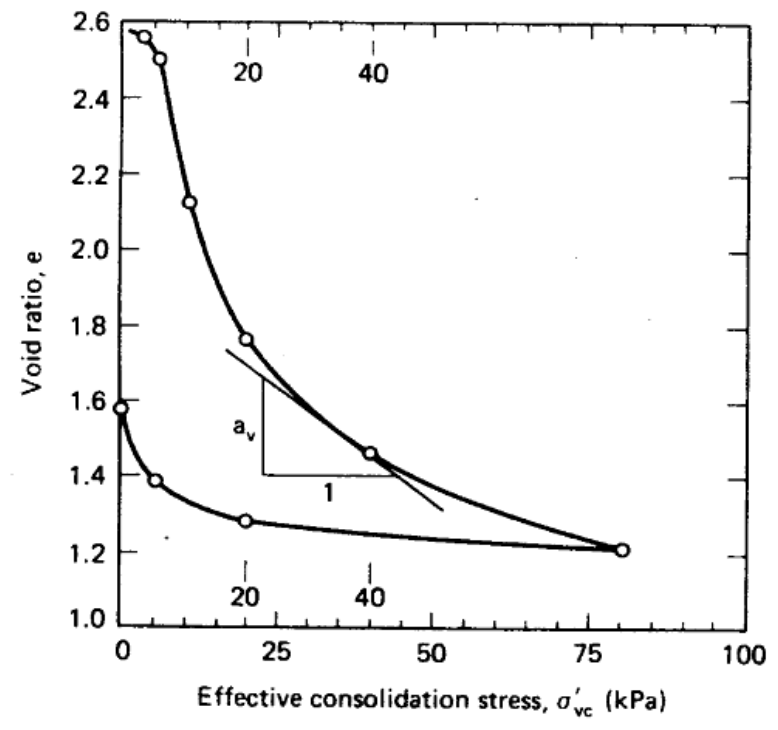

(b)

Gambar 4. Penyajian Data Hasil Uji Konsolidasi (a) Kurva $\varepsilon_{\mathrm{v}}-\sigma_{\mathrm{vc}}$ (b) Kurva e - $\sigma^{\prime}{ }_{v c}$ (Holtz and Kovac 1981)

Gambar 4 menunjukkan bahwa tanah adalah strain hardening material dimana modulus bertambah besar seiring dengan kenaikan tegangan.

Penyajian data hasil uji konsolidasi pada Gambar 4 dapat juga dilakukan dengan cara penggambaran kurva pada skala semi-log seperti ditunjukkan pada Gambar 5. 


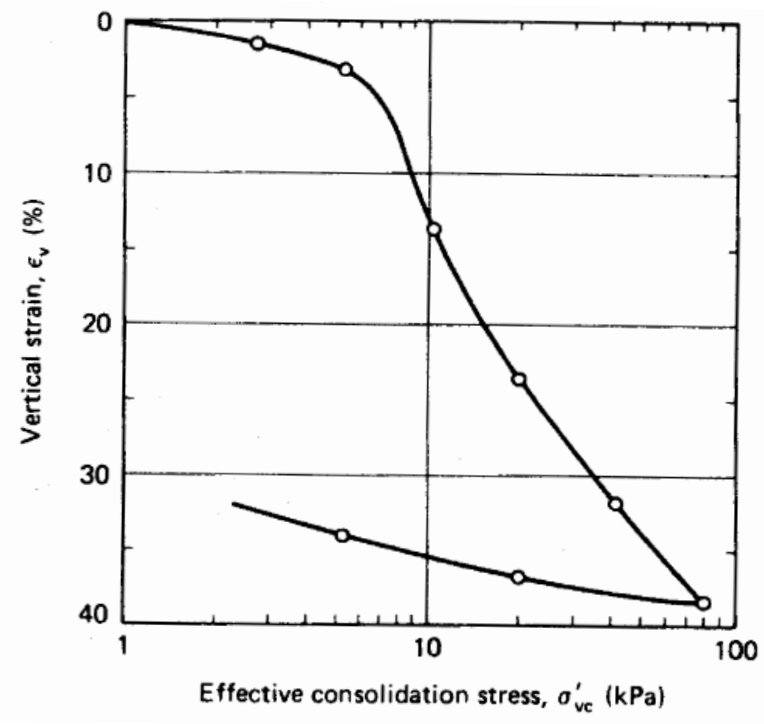

(a)

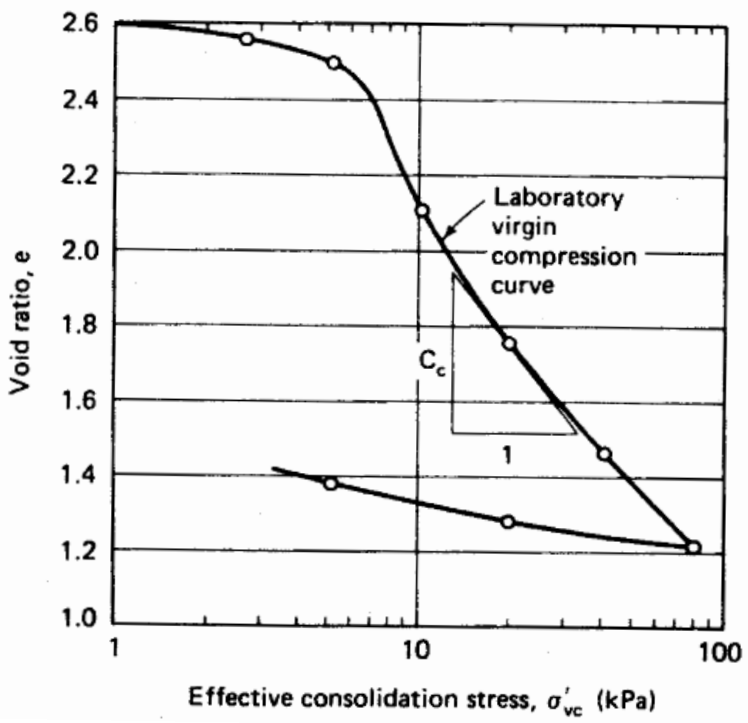

(b)

Gambar 5. Penyajian Data Hasil Uji Konsolidasi pada Skala Semi-Log

(a) Kurva $\varepsilon_{v}-\log \sigma^{\prime}{ }_{v c}(b)$ Kurva e $-\log \sigma^{\prime}{ }_{v c}($ Holtz and Kovac 1981)

Berdasarkan kurva seperti tampak pada Gambar 4.a, oedometric modulus, $\mathrm{E}_{\text {oed }}$ dapat diperoleh melalui persamaan berikut:

$$
E_{\text {oed }}=\frac{\Delta \sigma_{v c}^{\prime}}{\Delta \varepsilon_{v}}=\frac{1}{m_{v}}
$$




$$
m_{v}=\frac{a_{v}}{1+e_{0}}
$$

dimana:

$$
\begin{array}{ll}
\mathrm{E}_{\mathrm{oed}} & =\text { oedometric modulus / constrain modulus } \\
\varepsilon_{\mathrm{v}} & =\text { vertical strain } \\
\Delta \varepsilon_{\mathrm{v}} & =\text { change in vertical strain } \\
\sigma_{\mathrm{vc}} & =\text { effective consolidation stress } \\
\Delta \sigma^{\prime}{ }_{\mathrm{vc}} & =\text { range of effective consolidation stress } \\
\mathrm{m}_{\mathrm{v}} & =\text { coefficient of volume change / coefficient of volume compressibility } \\
\mathrm{a}_{\mathrm{v}} & =\text { coefficient of compressibility } \\
\mathrm{e}_{0} & =\text { initial void ratio }
\end{array}
$$

Tipikal nilai untuk oedometric modulus/constrained modulus, $\mathrm{E}_{\text {oed }}$ dinyatakan pada Tabel 1.

Tabel 1. Tipikal Nilai untuk Oedometric Modulus/Constrained Modulus, $\mathbf{E}_{\text {oed }}$ (Carter and Bentley 1991 dari Look 2007)

\begin{tabular}{lllll}
\hline Type of clay & \multicolumn{2}{c}{ Descriptive term } & $\begin{array}{l}\text { Coefficient of volume } \\
\text { compressibility, } \\
m_{v}\left(10^{-3} \mathrm{kPa}^{-1}\right)\end{array}$ & $\begin{array}{l}\text { Constrained } \\
\text { modulus, } \\
1 / \mathrm{m}_{v},(\mathrm{MPa})\end{array}$ \\
\cline { 2 - 5 } & Strength & Compressibility & $>20$ \\
\hline $\begin{array}{l}\text { Heavily overconsolidated } \\
\text { boulder clays, weathered } \\
\text { mudstone. }\end{array}$ & Hard & Very low & $<0.05$ & $10-20$ \\
$\begin{array}{l}\text { Boulder clays, tropical red } \\
\text { clays, moderately } \\
\text { overconsolidated. }\end{array}$ & Very stiff & Low & 0.05 to 0.1 & $3.3-10$ \\
$\begin{array}{l}\text { Glacial outwash clays, lake } \\
\text { deposits, weathered marl, }\end{array}$ & Firm & Medium & $0.1-0.3$ & \\
$\begin{array}{l}\text { lightly to normally } \\
\text { consolidated clays. }\end{array}$ & Soft & High & $0.3-1.0$ (non sensitive) & $0.7-3.3$ \\
$\begin{array}{l}\text { Normally consolidated } \\
\text { alluvial clays such as } \\
\text { estuarine and delta } \\
\text { deposits, and sensitive } \\
\text { clays. }\end{array}$ & & $0.5-2.0$ (organic, sensitive) & \\
$\begin{array}{l}\text { Highly organic alluvial } \\
\text { clays and peat. }\end{array}$ & Very soft & Very high & $>1.5$ & $<0.7$ \\
\hline
\end{tabular}

Crawford (1964) menyatakan pengaruh waktu pembebanan uji konsolidasi pada kurva e $-\log \sigma^{\prime}$ seperti tampak pada Gambar 6, dimana $\sigma^{\prime}$ adalah preconsolidation pressure dan $\sigma^{\prime}($ pressure $)=\sigma^{\prime}{ }_{\mathrm{vc}}$ (effective consolidation stress). 


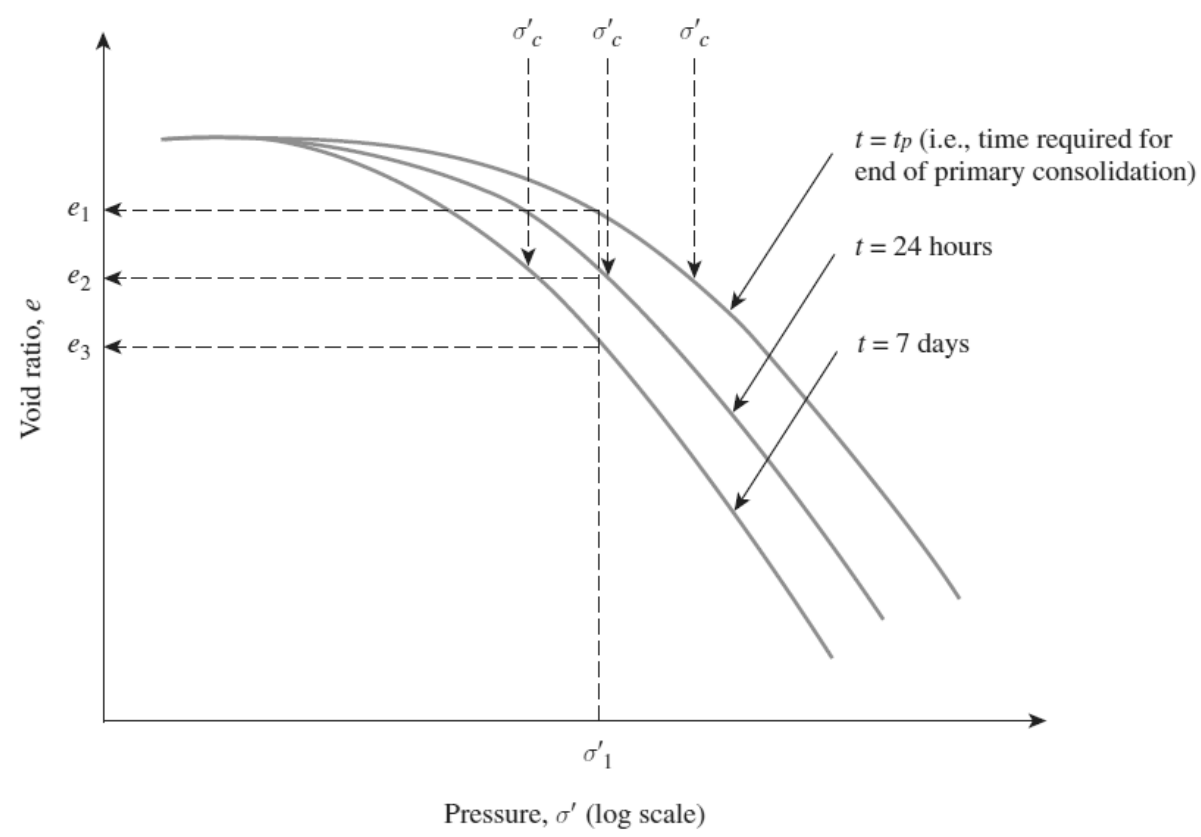

Gambar 6. Pengaruh Waktu Pembebanan pada Kurva e - $\log \sigma$ ' (Crawford 1964 dari Das and Sobhan 2014)

Sebagian dokumentasi untuk proses preparasi dan pembebanan uji konsolidasi pada penelitian ini tampak pada Gambar 7.

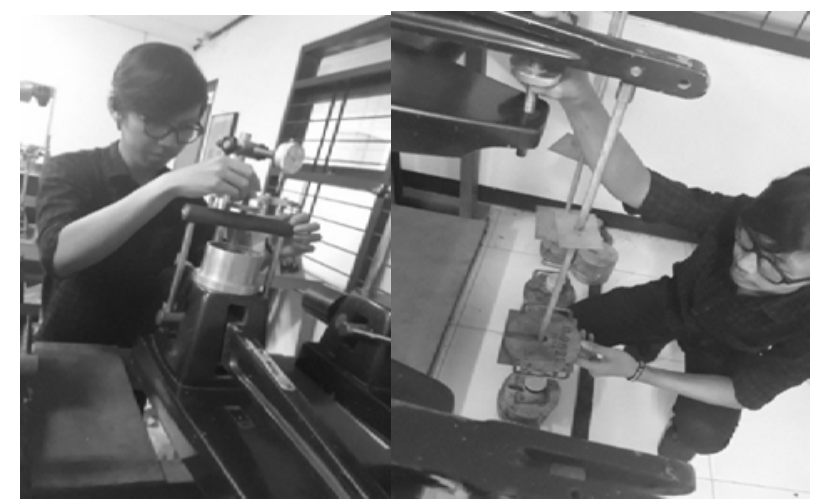

(a)

(b)

Gambar 7. Uji Konsolidasi di Laboratorium (a) Proses Preparasi

(b) Saat Pembebanan

\section{HASIL UJI DAN ANALISIS DATA}

\subsection{Nama Sampel, Klasifikasi, Konsistensi, dan Overvurden Stress Tanah}

Nama sampel, klasifikasi, konsistensi dan nilai overburden stress, $\sigma_{\text {vo }}$ dari sampel tanah uji dinyatakan pada Tabel 2 . 
Tabel 2. Nama Sampel, Klasifikasi, Konsistensi dan Overburden Stress Tanah

\begin{tabular}{ccccc}
\hline Borehole & $\begin{array}{c}\text { Nama } \\
\text { Sampel } \\
\text { Tanah Uji }\end{array}$ & Klasifikasi & Konsistensi & $\begin{array}{c}\text { Overburden } \\
\text { Stress, } \boldsymbol{\sigma}_{v o} \\
\text { (kPa) }\end{array}$ \\
\hline BH01-UDS1 & Sampel A & Silty Clay & Very Soft & 6,86 \\
BH02-UDS2 & Sampel B & Silty Clay & Very Soft & 24,36 \\
\hline
\end{tabular}

\subsection{Indeks Properti Tanah}

Initial water content (kadar air), w dan specific gravity, $\mathrm{G}_{\mathrm{s}}$ dari sampel tanah uji dinyatakan pada Tabel 3.

Tabel 3. Kadar Air dan Specific Gravity Tanah

\begin{tabular}{ccc}
\hline Sampel Uji & $\begin{array}{c}\text { Intial } \\
\text { Water Content, w } \\
(\%)\end{array}$ & $\begin{array}{c}\text { Specific } \\
\text { Gravity, } \mathbf{G}_{\mathbf{s}} \\
\text { (assumed) }\end{array}$ \\
\hline Sampel A & 101,1 & 2,6 \\
Sampel B & 79,21 & 2,6 \\
\hline
\end{tabular}

\subsection{Analisis Waktu Pembebanan terhadap Angka Pori (e) dan Tegangan Konsolidasi Efektif $\left(\boldsymbol{\sigma}^{\prime}{ }_{\mathrm{vc}}\right)$}

Waktu pembebanan yang digunakan untuk Sampel A dan Sampel B pada saat uji konsolidasi satu dimensi di laboratorium adalah 24 jam dan 48 jam untuk setiap kenaikan beban (load increament). Perbandingan nilai angka pori (void ratio), e dan tegangan konsolidasi efektif (effective consolidation stress), $\sigma^{\prime}{ }_{v c}$ terhadap waktu pembebanan sampel uji dinyatatakan pada Tabel 4 dan Tabel 5.

Tabel 4. Nilai Angka Pori (e) untuk Setiap Tegangan Konsolidasi Efektif $\left(\sigma^{{ }^{\prime}}{ }_{v c}\right)$

dan Waktu Pembeban pada Sampel A

\begin{tabular}{ccc} 
Effective & \multicolumn{2}{c}{ Void Ratio } \\
Consolidation Stress & \multicolumn{2}{c}{$\mathbf{e}$} \\
\cline { 2 - 3 } $\boldsymbol{\sigma}_{\mathbf{v c}}$ & \multicolumn{2}{c}{ Waktu Pembeban } \\
$(\mathbf{k P a})$ & $\mathbf{2 4}$ jam & $\mathbf{4 8}$ jam \\
\hline 0 & 2,81 & 2,81 \\
25 & 2,36 & 2,19 \\
50 & 2,07 & 1,89 \\
100 & 1,76 & 1,56 \\
200 & 1,47 & 1,28 \\
400 & 1,09 & 1,03
\end{tabular}




\begin{tabular}{ccc}
\hline Effective & \multicolumn{2}{c}{ Void Ratio } \\
\cline { 2 - 3 } $\begin{array}{c}\text { Consolidation Stress } \\
\boldsymbol{\sigma}_{\mathbf{v c}}\end{array}$ & \multicolumn{2}{c}{ Waktu Pembeban } \\
$(\mathbf{k P a})$ & $\mathbf{2 4} \mathbf{j a m}$ & $\mathbf{4 8}$ jam \\
800 & 0,85 & 0,76 \\
200 & 0,93 & 0,82 \\
800 & 0,83 & 0,74 \\
\hline
\end{tabular}

Tabel 5. Nilai Angka Pori (e) untuk Setiap Tegangan Konsolidasi Efektif $\left(\sigma^{{ }^{\prime}}{ }_{v c}\right)$ dan Waktu Pembebanan pada Sampel B

\begin{tabular}{ccc}
\hline $\begin{array}{c}\text { Effective } \\
\text { Consolidation Stress }\end{array}$ & \multicolumn{2}{c}{$\begin{array}{c}\text { Void Ratio } \\
\text { e }\end{array}$} \\
\cline { 2 - 3 } $\boldsymbol{\sigma}_{\mathbf{v c}}$ & \multicolumn{2}{c}{ Waktu Pembeban } \\
(kPa) & $\mathbf{2 4}$ jam & $\mathbf{4 8 ~ j a m ~}$ \\
\hline 0 & 2,39 & 2,14 \\
25 & 2,18 & 1,97 \\
50 & 1,99 & 1,80 \\
100 & 1,76 & 1,58 \\
200 & 1,50 & 1,34 \\
400 & 1,20 & 1,12 \\
800 & 0,97 & 0,88 \\
200 & 1,04 & 0,93 \\
800 & 0,95 & 0,87 \\
\hline
\end{tabular}

Tabel 4 dan Tabel 5 menunjukkan bahwa seluruh angka pori pada Sampel A dan Sampel B yang diuji dengan waktu pembebanan 48 jam memiliki nilai yang lebih kecil dibanding dengan sampel yang diuji dengan waktu pembebanan 24 jam. Hal ini dapat terjadi karena pemampatan terjadi lebih lama pada saat sampel diuji dengan waktu pembebanan 48 jam.

Selisih nilai angka pori, $\Delta \mathrm{e}$ untuk $\sigma^{\prime}{ }_{\mathrm{vc}} 25 \mathrm{kPa}$ hingga $\sigma^{\prime}{ }_{\mathrm{vc}} 800 \mathrm{kPa}$ untuk Sampel A adalah 1,53 untuk waktu pembebanan 24 jam dan 1,45 untuk waktu pembebanan 48 jam. Sementara selisih nilai angka pori, $\Delta \mathrm{e}$ untuk $\sigma^{\prime}{ }_{\mathrm{vc}} 25 \mathrm{kPa}$ hingga $\sigma^{\prime}{ }_{\mathrm{vc}} 800 \mathrm{kPa}$ untuk Sampel B adalah 1,23 untuk waktu pembebanan 24 jam dan 1,10 untuk waktu pembebanan 48 jam.

Kurva hubungan antara void ratio, e dan effective cosolidation stress, $\sigma^{\prime}{ }_{\mathrm{vc}}$ dengan waktu pembebanan 24 jam dan 48 jam pada skala semi-log tampak pada Gambar 8 dan Gambar 9. 


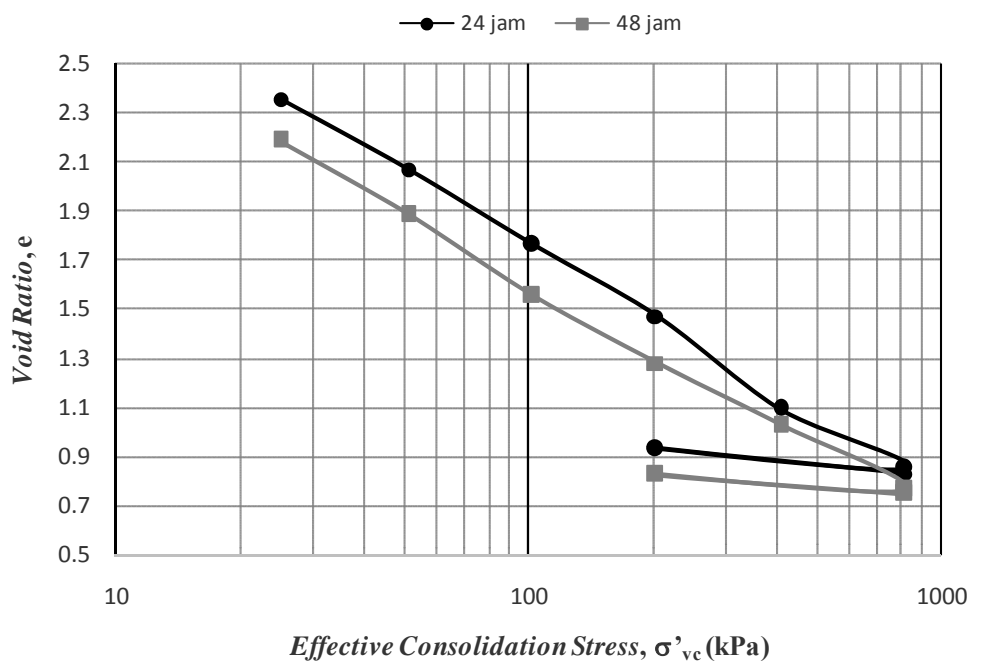

Gambar 8. Kurva e - $\log \sigma_{v c}^{\prime}$ Sampel A

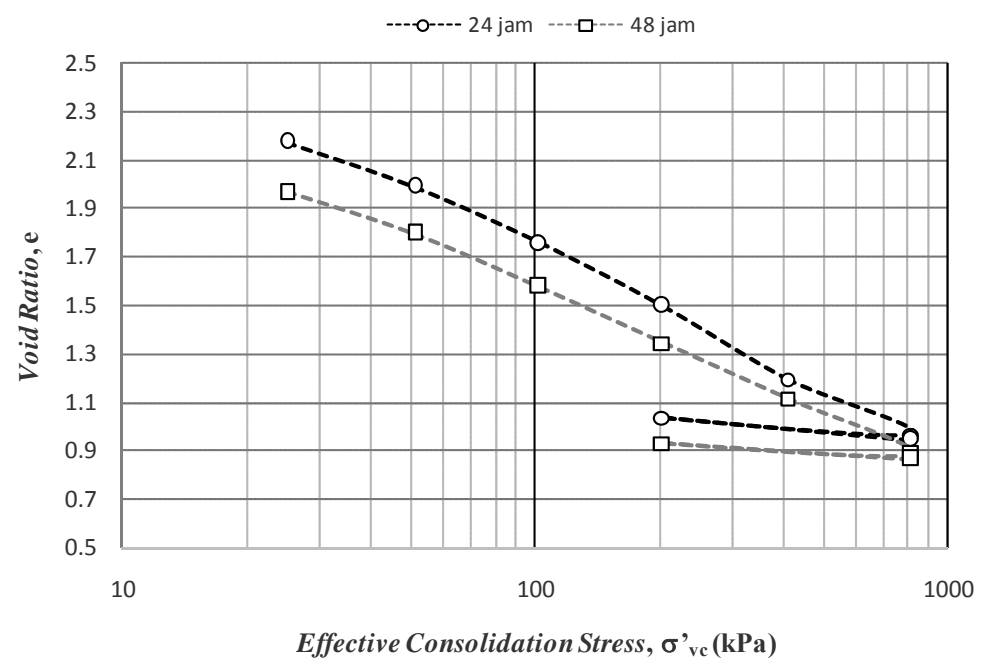

Gambar 9. Kurva e - $\log \sigma_{\text {vc }}$ Sampel B

Gambar 8 dan Gambar 9 menunjukkan bahwa kurva e - $\log \sigma^{\prime}{ }_{v c}$ Sampel A dan Sampel B dengan waktu pembebanan 24 jam selalu berada di atas kurva e - log $\sigma^{\prime}{ }_{v c}$ dengan waktu pembebanan 48 jam. Hal ini menunjukkan bahwa sampel yang diuji dengan waktu pembebanan 48 jam mengalami pemampatan yang lebih besar dibanding dengan sampel dengan waktu pembebanan 24 jam.

Kuva e - $\log \sigma^{\prime}$ vc gabungan untuk Sample A dan Sampel B tampak pada Gambar 10. Kuva e $-\log \sigma^{\prime}$ vc Sample A berada di atas kuva e - $\log \sigma_{\text {vc }}$ Sample B untuk waktu 
pembebanan 24 jam dan 48 jam, hal ini diduga disebabkan oleh karena nilai overburden stress, $\sigma{ }_{\text {vo }}$ Sample A $(6,86 \mathrm{kPa})$ lebih kecil dari Sampel B (24.36kPa).

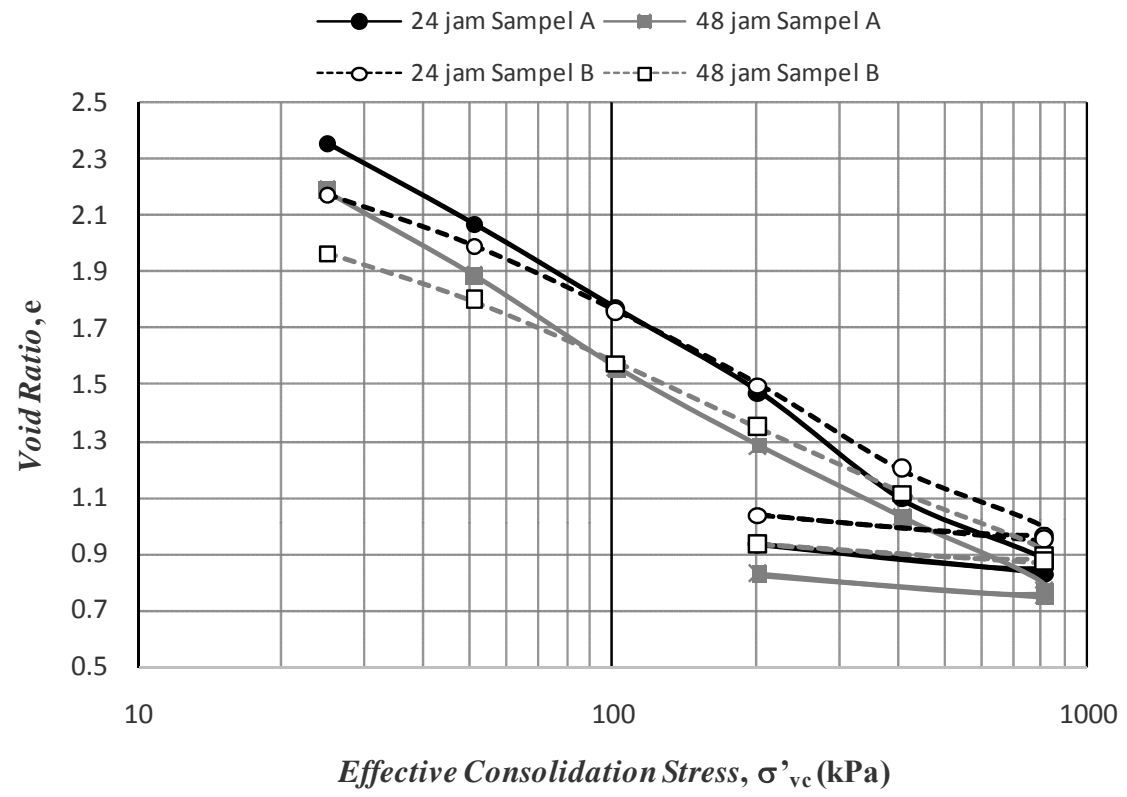

Gambar 10. Kurva e - $\log \sigma^{\prime}{ }_{v c}$ Gabungan untuk Sampel A dan Sampel B

\subsection{Analisis Waktu Pembebanan terhadap Regangan Vertikal $\left(\varepsilon_{v}\right)$ dan Tegangan Konsolidasi Efektif $\left(\sigma^{\prime}{ }_{v c}\right)$}

Nilai regangan vertikal, $\varepsilon_{\mathrm{v}}$ pada uji konsolidasi di laboratorium dapat diperoleh dari perubahan tinggi sampel uji, $\Delta \mathrm{h}$ hasil pembacaan vertical dial dibagi tinggi awal sampel uji, h. Sementara data tegangan konsolidsi efektif, $\sigma^{\prime}{ }_{v c}$ dapat diperoleh dari beban yang diberikan selama pengujian konsolidasi satu dimensi, P dibagi dengan luas penampang sampel uji, A.

Nilai regangan vertikal $\left(\varepsilon_{\mathrm{v}}\right)$ dengan waktu pembebanan 24 jam dan 48 jam untuk setiap tegangan konsolidasi efektif $\left(\sigma^{\prime}{ }_{\text {vc }}\right)$ pada Sampel A dan Sampel B dinyatakan pada Tabel 6 dan Tabel 7.

Tabel 6 menunjukkan bahwa regangan vertikal, $\varepsilon_{\mathrm{v}}$ pada Sampel A dengan waktu pembebanan 48 jam lebih besar jika dibandingkan dengan $\varepsilon_{\mathrm{v}}$ dengan waktu pembebanan 24 jam. Hal ini berbeda dengan Sampel B seperti dinyatakan pada Tabel 7 bahwa $\varepsilon_{\mathrm{v}}$ dengan waktu pembebanan 48 jam lebih kecil jika dibandingkan dengan $\varepsilon_{\mathrm{v}}$ dengan waktu pembebanan 24 jam. 
Tabel 6. Regangan Vertikal $\left(\varepsilon_{v}\right)$ untuk Setiap Tegangan Konsolidasi Efektif $\left(\sigma^{{ }^{\prime}}{ }_{v c}\right)$ dan Waktu Pembebanan pada Sampel A

\begin{tabular}{ccc}
\hline $\begin{array}{c}\text { Effective } \\
\text { Consolidation Stress }\end{array}$ & \multicolumn{2}{c}{$\begin{array}{c}\text { Vertical Strain } \\
\boldsymbol{\varepsilon}_{\mathbf{v}}(\mathbf{\%})\end{array}$} \\
\cline { 2 - 3 } $\boldsymbol{\sigma}_{\mathbf{v c}}$ & \multicolumn{2}{c}{ Waktu Pembebanan } \\
$\mathbf{( k P a )}$ & $\mathbf{2 4} \mathbf{~ j a m}$ & $\mathbf{4 8 ~ j a m ~}$ \\
\hline 0 & 0,00 & 0,00 \\
25 & 11,79 & 16,23 \\
50 & 19,29 & 24,18 \\
100 & 27,34 & 32,82 \\
200 & 35,07 & 40,07 \\
400 & 45,02 & 46,73 \\
800 & 51,32 & 53,68 \\
\hline
\end{tabular}

Tabel 7. Regangan Vertikal $\left(\varepsilon_{v}\right)$ untuk Setiap Tegangan Konsolidasi Efektif $\left(\sigma^{{ }^{\prime}}{ }_{v c}\right)$ dan Waktu Pembebanan pada Sampel B

\begin{tabular}{ccc} 
Effective & \multicolumn{2}{c}{$\begin{array}{c}\text { Vertical Strain } \\
\boldsymbol{\varepsilon}_{\mathbf{v}}(\mathbf{\%})\end{array}$} \\
\cline { 2 - 3 } $\begin{array}{c}\boldsymbol{\sigma}_{\mathbf{v c}} \\
(\mathbf{k P a})\end{array}$ & \multicolumn{2}{c}{ Waktu Pembebanan } \\
$\mathbf{2 4}$ jam & $\mathbf{4 8}$ jam \\
\hline 0 & 0,00 & 0,00 \\
25 & 6,36 & 5,46 \\
50 & 11,78 & 10,87 \\
100 & 18,74 & 17,91 \\
200 & 26,39 & 25,30 \\
400 & 35,23 & 32,57 \\
800 & 41,97 & 39,94 \\
\hline
\end{tabular}

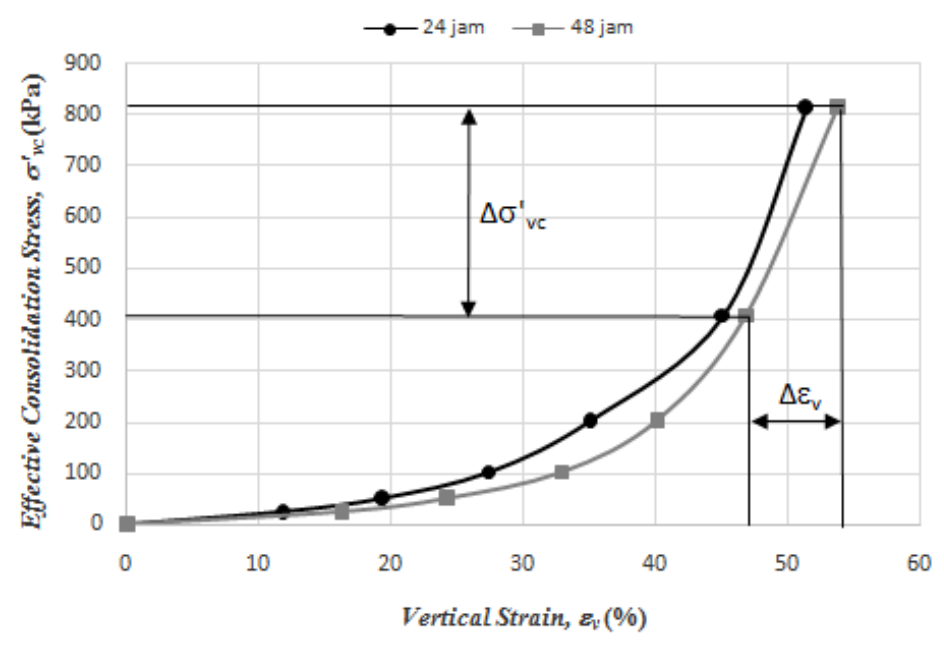

Gambar 11. Kurva $\varepsilon_{\mathrm{v}}-\sigma^{\prime}{ }_{\mathrm{vc}}$ Sampel A 


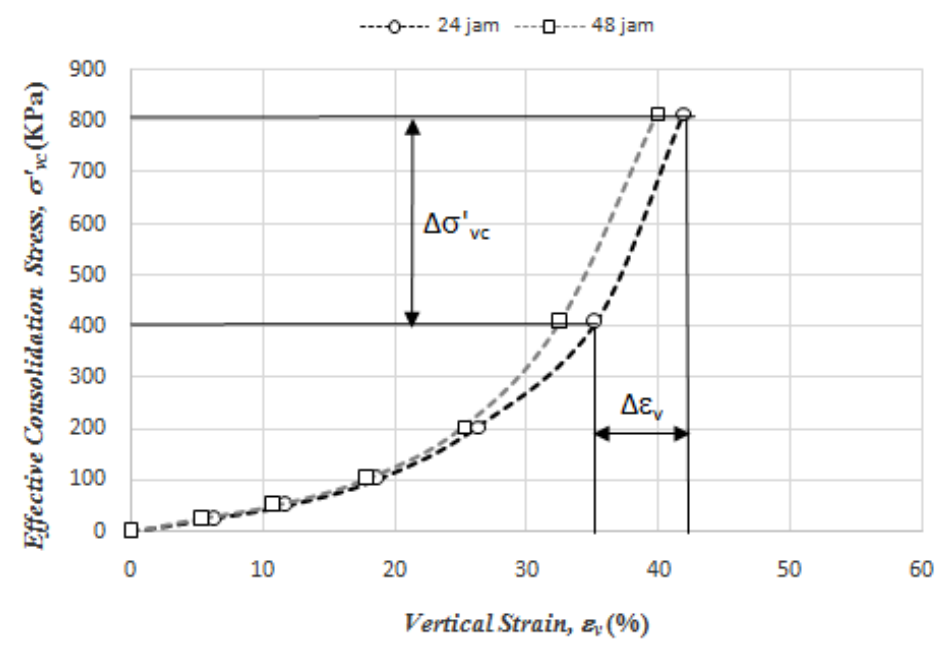

Gambar 12. Kurva $\varepsilon_{v}-\sigma_{v c}^{\prime}$ Sampel B

Kurva $\varepsilon_{\mathrm{v}}-\sigma^{\prime}{ }_{\mathrm{vc}}$ dengan waktu pembebanan 24 jam dan 48 jam untuk Sampel A dan Sampel B tampak pada Gambar 11 dan Gambar 12. Gambar 11 menunjukkan bahwa kurva $\varepsilon_{\mathrm{v}}-\sigma_{\mathrm{vc}}$ Sampel A untuk waktu pembebanan 24 jam berada di sebelah kiri urva $\varepsilon_{\mathrm{v}}$ - $\sigma_{\text {vc }}^{\prime}$ dengan waktu pembebanan 48 jam untuk Sampel A. Sementara untuk Sampel B seperti ditunjukkan pada Gambar 12, kurva $\varepsilon_{\mathrm{v}}-\sigma_{\mathrm{vc}}^{\prime}$ untuk waktu pembebanan 24 jam berada di sebelah kanan kurva $\varepsilon_{\mathrm{v}}-\sigma^{\prime}{ }_{\mathrm{vc}}$ dengan waktu pembebanan 48 jam.

\subsection{Analisis Pengaruh Waktu Pembebanan terhadap Oedometric Modulus, $\mathbf{E}_{\text {oed }}$}

Nilai oedometric modulus, $\mathrm{E}_{\text {oed }}$ untuk Sampel A dan Sampel B dapat diperoleh dengan menggunakan Persamaan 1 dan berdasarkan pada kurva $\varepsilon_{\mathrm{v}}-\sigma^{\prime}{ }_{\mathrm{vc}}$. Kurva $\varepsilon_{\mathrm{v}}-\sigma^{\prime}{ }_{\mathrm{vc}}$ gabungan dengan waktu pembebanan 24 jam dan 48 jam untuk Sampel A dan Sampel B tampak pada Gambar 13.

Gambar 13 menunjukkan bahwa kurva $\varepsilon_{\mathrm{v}}-\sigma_{\mathrm{vc}}^{\prime}$ dengan waktu pembebanan 24 jam dan 48 jam untuk Sampel B berada disebelah kiri kurva Sampel A. Hal ini menyatakan bahwa nilai regangan vertikal, $\varepsilon_{\mathrm{v}}$ Sampel B lebih kecil dari Sampel A untuk setiap tegangan konsolidasi efektif, $\sigma^{\prime}$ vc yang bekerja. Pada seluruh kurva $\varepsilon_{\mathrm{v}}-\sigma^{\prime}{ }_{\mathrm{vc}}$ dengan waktu pembebanan 24 jam maupun 48 jam menunjukkan bahwa, trend linier pada kurva terjadi saat tegangan konsolidasi efektif dibawah 100kPa. Kemudian tampak "kurva transisi" pada saat tegangan konsolidsi efektif antara $100 \mathrm{kPa}$ hingga $400 \mathrm{kPa}$ dan pada akhirnya kurva kembali menunjukkan trend linier saat tegangan konsolidasi efektif melebihi 400kPa. 
Nilai $E_{\text {oed }}$ untuk kedua sampel uji dinyatakan berturut-turut pada Tabel 7 dan Tabel 8 .

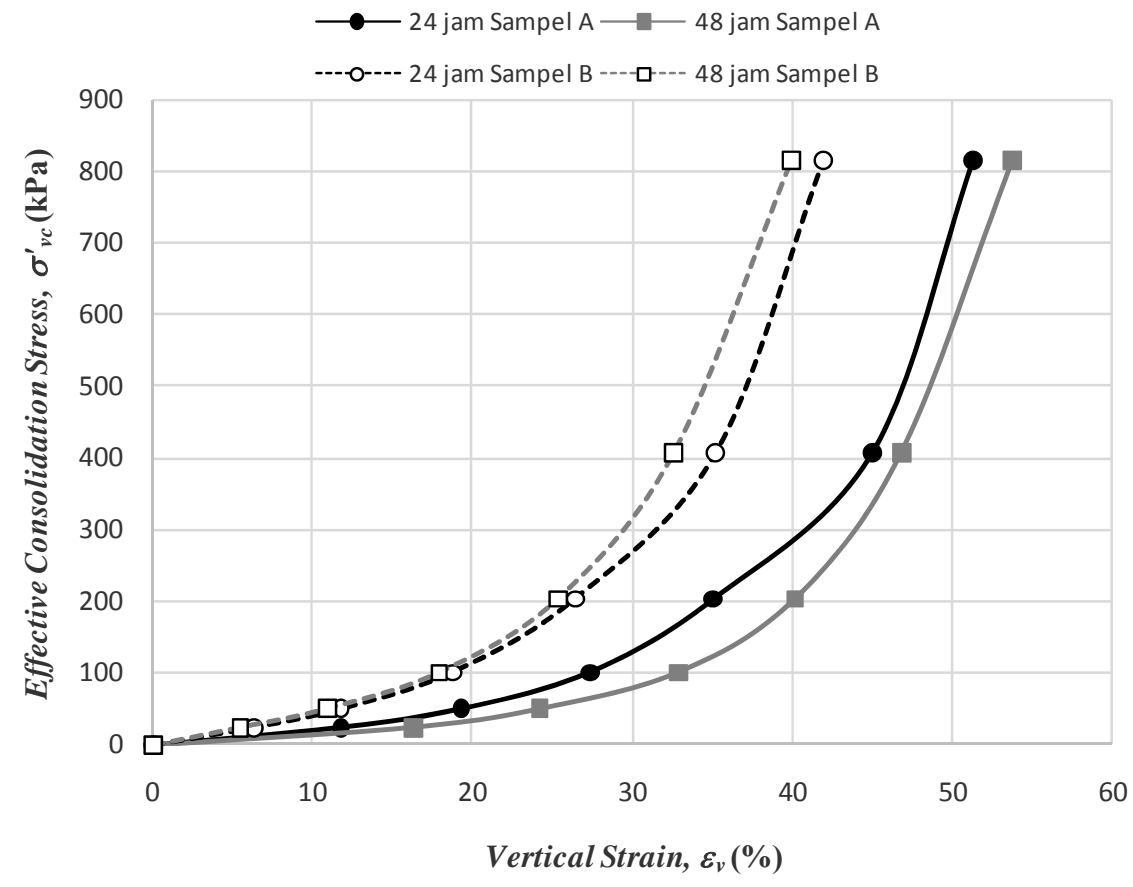

Gambar 13. Kurva $\varepsilon_{\mathrm{v}}-\sigma^{\prime}{ }_{\mathrm{vc}}$ Gabungan untuk Sampel A dan Sampel B

Tabel 7. Nilai $E_{\text {oed }}$ Sampel A untuk Setiap $\Delta \sigma^{\prime}{ }_{\text {ve }}$ dan Waktu Pembebanan

\begin{tabular}{|c|c|c|c|}
\hline \multirow{3}{*}{$\begin{array}{c}\text { Range of } \\
\text { Effective } \\
\text { Consolidation Stress } \\
\Delta \sigma^{\prime}{ }_{v c} \\
(\mathrm{kPa})\end{array}$} & \multicolumn{2}{|c|}{$\begin{array}{c}\text { Oedometric Modulus } \\
\text { E }_{\text {oed }} \text { (MPa) }\end{array}$} & \multirow{3}{*}{$\begin{array}{c}\text { Selisih } \\
\mathrm{E}_{\text {oed }} 48 \text { jam } \\
\text { terhadap } \\
\mathrm{E}_{\text {oed }} 24 \text { jam } \\
\text { (MPa) }\end{array}$} \\
\hline & \multicolumn{2}{|c|}{ Waktu Pembebanan } & \\
\hline & 24 jam & 48 jam & \\
\hline $0-25$ & 0,21 & 0,15 & $-0,06$ \\
\hline $25-50$ & 0,35 & 0,33 & $-0,02$ \\
\hline $50-100$ & 0,63 & 0,59 & $-0,04$ \\
\hline $100-200$ & 1,32 & 1,41 & 0,09 \\
\hline $200-400$ & 2,05 & 3,06 & 1,01 \\
\hline $400-800$ & 6,47 & 5,87 & $-0,6$ \\
\hline
\end{tabular}

Keterangan: Tanda negatif $(-)=$ nilai $\mathrm{E}_{\text {oed }}$ turun

Nilai $\mathrm{E}_{\mathrm{oed}}$ meningkat seiring dengan peningkatan range of effective consolidation stress, $\Delta \sigma^{\prime}{ }_{\text {vc }}$ baik untuk Sampel A dan Sampel B seperti ditunjukkan pada Tabel 7 dan Tabel 8. Nilai $E_{\text {oed }}$ pada Sampel A dengan waktu pembebanan 48 jam lebih kecil dari nilai 
$\mathrm{E}_{\text {oed }}$ dengan waktu pembebanan 24 jam saat $\Delta \sigma^{\prime}{ }_{\mathrm{vc}}$ dibawah $100 \mathrm{kPa}$ dengan selisih $\mathrm{E}_{\mathrm{oed}}$ bekisar antara 0,02-0,06 MPa. Nilai $\mathrm{E}_{\text {oed }}$ dengan waktu pembebanan 48 jam lebih besar dari nilai $\mathrm{E}_{\mathrm{oed}}$ dengan waktu pembebanan 24 jam saat $\Delta \sigma^{\prime}{ }_{\mathrm{vc}}=200-400 \mathrm{kPa}$ dengan selisih sebesar 1,01MPa.

Nilai $E_{\text {oed }}$ pada Sampel B dengan waktu pembebanan 48 jam lebih besar dari nilai $\mathrm{E}_{\text {oed }}$ dengan waktu pembebanan 24 jam saat $\Delta \sigma^{\prime}{ }_{v c}$, dengan selisih $\mathrm{E}_{\text {oed }}$ tertinggi sebesar $0,49 \mathrm{MPa}$ saat $\Delta \sigma^{\prime}{ }_{\mathrm{vc}}=200-400 \mathrm{kPa}$.

Tabel 8. Nilai $E_{\text {oed }}$ Sampel B untuk Setiap $\Delta \sigma^{\prime}{ }_{v c}$ dan Waktu Pembebanan

\begin{tabular}{|c|c|c|c|}
\hline \multirow{3}{*}{$\begin{array}{c}\text { Range of } \\
\text { Effective } \\
\text { Consolidation Stress } \\
\Delta \sigma_{\mathrm{vc}}^{\prime} \\
(\mathrm{kPa})\end{array}$} & \multicolumn{2}{|c|}{$\begin{array}{c}\text { Oedometric Modulus } \\
\mathbf{E}_{\text {oed }}(\mathbf{M P a})\end{array}$} & \multirow{3}{*}{$\begin{array}{c}\text { Selisih } \\
\mathrm{E}_{\text {oed }} 48 \text { jam } \\
\text { terhadap } \\
\mathrm{E}_{\text {oed }} 24 \text { jam } \\
\text { (MPa) }\end{array}$} \\
\hline & \multicolumn{2}{|c|}{ Waktu Pembebanan } & \\
\hline & 24 jam & 48 jam & \\
\hline $0-25$ & 0,39 & 0,46 & 0,07 \\
\hline $25-50$ & 0,47 & 0,48 & 0,01 \\
\hline $50-100$ & 0,73 & 0,72 & $-0,01$ \\
\hline $100-200$ & 1,33 & 1,38 & 0,05 \\
\hline $200-400$ & 2,31 & 2,80 & 0,49 \\
\hline $400-800$ & 6,06 & 5,54 & $-0,52$ \\
\hline
\end{tabular}

Keterangan: Tanda negatif $(-)=$ nilai $\mathrm{E}_{\text {oed }}$ turun

Nilai $E_{\text {oed }}$ Sampel A dan Sampel B pada saat $\sigma^{\prime}{ }_{\text {vc }}$ lebih kecil dari $400 \mathrm{kPa}$ untuk waktu pembebanan 24 jam dan 48 jam, berkisar antara 0,15-3,06MPa. Berdasarkan tabel tipikal nilai $\mathrm{E}_{o e d}$ dari Carter and Bentley (1991) yang dinyatakan pada Tabel 1, nilai $\mathrm{E}_{\text {oed }}$ yang diperoleh untuk Sampel A dan Sampel B tersebut masuk kedalam strength; very soft hingga soft. Hal ini menunjukkan kesesuaian dengan Sampel A dan Sampel B yang memiliki konsistensi very soft.

Diagram pengaruh waktu pembebanan terhadap nilai $\mathrm{E}_{\mathrm{oed}}$ Sampel A dan Sampel B untuk setiap $\Delta \sigma^{\prime}{ }_{\text {cc }}$ tampak pada Gambar 14 dan Gambar 15. 


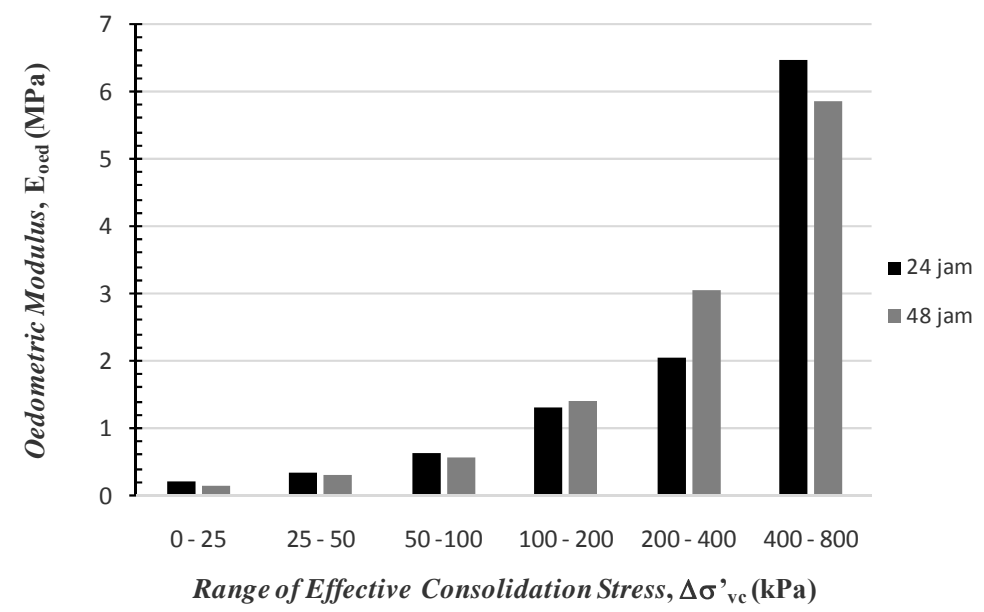

Gambar 14. Diagram Pengaruh Waktu Pembebanan terhadap Nilai $\mathbf{E}_{\text {oed }}$ Sampel A untuk Setiap $\Delta \sigma^{\prime}{ }_{v c}$

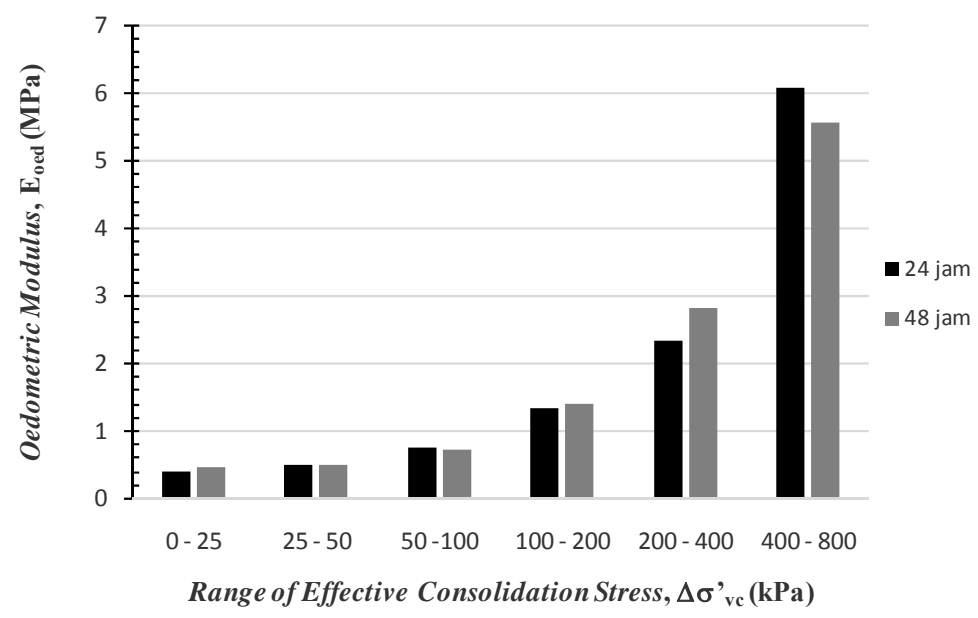

Gambar 14. Diagram Pengaruh Waktu Pembebanan terhadap Nilai $E_{\text {oed }}$ Sampel B untuk Setiap $\Delta \sigma^{\prime}{ }_{v c}$

Persentase perbandingan $\mathrm{E}_{\text {oed }}$ dengan waktu pembebanan 48 jam terhadap $\mathrm{E}_{\mathrm{oed}}$ dengan waktu pembebanan 24 jam untuk Sampel A dan Sampel B dinyatakan berturutturut pada Tabel 9 dan Tabel 10. 
Tabel 9. Nilai $E_{\text {oed }}$ dan Persentase Perbandingan $E_{\text {oed }} 48$ jam terhadap $E_{\text {oed }} 24$ jam untuk Sampel A

\begin{tabular}{|c|c|c|c|}
\hline $\begin{array}{c}\text { Range of } \\
\text { Effective } \\
\text { Consolidation } \\
\text { Stress } \\
\Delta \sigma^{\prime}{ }^{\prime} \\
(\mathrm{kPa}) \\
\end{array}$ & $\begin{array}{c}\mathbf{E}_{\text {oed }} \\
\text { Waktu Pembebanan } \\
24 \text { jam } \\
(\mathrm{MPa})\end{array}$ & $\begin{array}{c}\mathbf{E}_{\text {oed }} \\
\text { Watku Pembebanan } \\
48 \text { jam } \\
(\mathrm{MPa})\end{array}$ & $\begin{array}{c}\text { Persentase } \\
\text { Perbandingan } \\
\mathbf{E}_{\text {oed } 48 \text { jam }} \\
\text { terhadap } \\
\mathbf{E}_{\text {oed 24 jam }} \\
(\%) \\
\end{array}$ \\
\hline $0-25$ & 0,21 & 0,15 & $-27,4$ \\
\hline $25-50$ & 0,35 & 0,33 & $-5,5$ \\
\hline $50-100$ & 0,63 & 0,59 & $-6,9$ \\
\hline $100-200$ & 1,32 & 1,41 & 6,5 \\
\hline $200-400$ & 2,05 & 3,06 & 49,4 \\
\hline $400-800$ & 6,47 & 5,87 & $-9,3$ \\
\hline
\end{tabular}

Keterangan : Tanda negatif $(-)=$ penurunan nilai perbandingan $\mathrm{E}_{\text {oed }}$

Tabel 10. Nilai $E_{o e d}$ dan Persentase Perbandingan $E_{o e d} 48$ jam terhadap $E_{o e d} 24$ jam untuk Sampel B

\begin{tabular}{|c|c|c|c|}
\hline $\begin{array}{c}\text { Range of } \\
\text { Effective } \\
\text { Consolidation } \\
\text { Stress } \\
\Delta \sigma_{\mathrm{vc}}^{\prime} \\
(\mathrm{kPa}) \\
\end{array}$ & $\begin{array}{c}\mathbf{E}_{\text {oed }} \\
\text { Waktu Pembebanan } \\
24 \text { jam } \\
(\mathrm{MPa})\end{array}$ & $\begin{array}{c}\mathbf{E}_{\text {oed }} \\
\text { Waktu Pembebanan } \\
48 \text { jam } \\
(\mathrm{MPa})\end{array}$ & $\begin{array}{c}\text { Persentase } \\
\text { Perbandingan } \\
\text { E }_{\text {oed } 48 \text { jam }} \\
\text { terhadap } \\
\mathbf{E}_{\text {oed 24 jam }} \\
(\%) \\
\end{array}$ \\
\hline $0-25$ & 0,39 & 0,46 & 16,4 \\
\hline $25-50$ & 0,47 & 0,48 & 0,4 \\
\hline $50-100$ & 0,73 & 0,72 & $-1,3$ \\
\hline $100-200$ & 1,33 & 1,38 & 3,6 \\
\hline $200-400$ & 2,31 & 2,80 & 21,6 \\
\hline $400-800$ & 6,06 & 5,54 & $-8,5$ \\
\hline
\end{tabular}

Keterangan: Tanda negatif $(-)=$ penurunan nilai perbandingan $\mathrm{E}_{\mathrm{oed}}$

Tabel 9 dan Tabel 10 menunjukkan bahwa waktu pembebanan mempengaruhi nilai oedometric modulus, $\mathrm{E}_{\text {oed }}$ baik pada Sampel A maupun pada Sampel B. Persentase terbesar untuk perbandingan nilai $\mathrm{E}_{\text {oed }}$ dengan waktu pembebanan 48 jam terhadap $\mathrm{E}_{\text {oed }}$ dengan waktu penbebanan 24 tercapai pada saat $\Delta \sigma^{\prime}{ }_{v c}=200-400 \mathrm{kPa}$ dengan nilai persentase berturut-turut; 49,4\% untuk Sampel A dan 21,6\% untuk Sampel B.

\section{SIMPULAN}

Simpulan yang diperoleh dari penelitian ini antara lain adalah:

1. Nilai oedometric modulus, $\mathrm{E}_{\mathrm{oed}}$ dengan waktu pembebanan 48 jam lebih besar dari nilai oedometric modulus, $\mathrm{E}_{\text {oed }}$ dengan waktu pembebanan 24 jam dengan selisih 
tertinggi sebesar 1,01MPa untuk Sampel A dan 0,49MPa untuk Sampel B dan keduanya terjadi pada saat $\Delta \sigma^{\prime}{ }_{\mathrm{vc}}=200-400 \mathrm{kPa}$.

2. Nilai $\mathrm{E}_{\text {oed }}$ dengan waktu pembebanan 48 jam lebih besar $49.4 \%$ dari $\mathrm{E}_{\text {oed }}$ dengan waktu pembebanan 24 jam untuk Sampel A. Sementara pada Sampel B, nilai $E_{\text {oed }}$ dengan waktu pembebanan 48 jam lebih besar $21.6 \%$ dari $\mathrm{E}_{\text {oed }}$ dengan waktu pembebanan 24 jam.

3. Waktu pembebanan berpengaruh terhadap nilai oedometic modulus, $\mathrm{E}_{\mathrm{oed}}$ tanah silty clay dengan konsistensi very soft terutama pada saat rentang tegangan konsolidasi efektif, $\Delta \sigma^{\prime}{ }_{\mathrm{vc}}=200-400 \mathrm{kPa}$.

\section{SARAN}

Disarankan untuk melakukan penelitian lebih lanjut mengenai pengaruh overburden stress dan load of increament ratio (LIR) terhadap nilai eodometric modulus, $\mathrm{E}_{\text {oed }}$ tanah silty clay.

\section{DAFTAR PUSTAKA}

1. ASTM D 2216-98, Standard Test Methods for Laboratory Determination of Water (Moisture Content) of Soil and Rock by Mass, Annual Book of ASTM Standards.

2. ASTM D 2435-03, Standard Test Methods for One-Dimensional Consolidation Properties of Soils Using Incremental Loading, Annual Book of ASTM Standards.

3. ASTM D 2487-00, Standard Practice for Classification of soils for Engineering Purposes (Unified Soil Classificication System), Annual Book of ASTM Standards.

4. Carter, M. and Bentley, S.P., 1991, Correlations of Soil Properties, Pentech Press, London.

5. Crawford, C. B., 1964, Interpretation of the Consolidation Tests, Journal of the Soil Mechanics and Foundations Division, ASCE, Vol. 90, No. SM5, pp. 93-108.

6. Das, B.M. and Shoban, K, 2014, Principles of Geotechnical Engineering, SI, $8^{\text {th }}$ Ed., Cengage Learning, Standford, USA.

7. Holtz, R.D. and Kovacs, W.D., 1981, An Introduction to Geotechnical Engineering, $2^{\text {nd }}$ Ed., Prentice Hall, New Jersey, USA.

8. Look, B.G., 2007, Handbook of Geotechnical Inverstigation and Design Tables, Taylor and Francis, London, UK. 